\title{
The Crisis Management Practices: The Case of Egyptian Hotels
}

\section{Yasser Mahmoud Ashraf El Sayed Abd El Maaboud $\quad$ EL Hussein Ali. Faculty of Tourism and Hotels, Fayoum University}

\section{Abstract}

This research attempts to assess crisis management practices used in 3- \& 4-star hotels in great Cairo and Sharm El Sheikh. an integrated approach is implemented to enhance the crisis management system of the hotels. Moreover, the research aims to exploring the crisis management practices which applied and illustrate which practices managers consider important and which practices managers actually use during a crisis. Data collection technique for the research will be a questionnaire to collect data from different head of Departments or Assistants in 3 \& 4-star hotels in great Cairo and Sharm El Sheikh. The questionnaire was sent to 450 participants Responses were received from 400 participants (89\%). Obtained data will be analyzed using SPSS version 22.

The results of this research explain that $3 \& 4$ star hotels in great Cairo and Sharm El Sheikh must respond to internal and external hazards such as disease movement and terrorist attacks, Crisis management plan is important to promote hotels and tourist destinations to the guests and holiday advisors. Hotels invest a lot to install protective techniques, Practitioners propose disaster management frameworks using several measurements. Recovery from crisis and learning help business retention that minimizes negative impacts and prevent losses. Finally, effective crisis management plan C.M.P. and organized practices are very important to overcome the hazards and return to normal. It is suggested that knowledge management principles can improve crisis management and planning. To that extent, a conceptual framework is offered.

The research has provided hotels managers with some feedback on the overall perception of their CMP and the practices better to use in case of crises. The research has indicated That There is a positive significant statistical relationship between the crisis management practices using incase of crises and booth of the head of department's awareness about (the concept and functions) and (the Effects and Benefits) of the crises management plan (CMP).

Moreover, Most of respondents indicated that the most Practices may use in case of crisis is (Replacing high-tenure employees with line employees), followed by (Freezing pay rates), followed by (Firing employees to reduce labor force), which means that in case of any crisis the hotels industry lost a lot of experienced employees which very dangerous for the industry in case the crisis take a long term. And also, The results from the research indicated that an overall average of the Practices may use in case of crisis in Sharm hotels more than in Cairo hotels.

Keywords: Crises Management Plan, Practices, Head of Departments, Hotel, Egypt.

\section{Introduction}

According to Qoura and Ali, (2015) stated that the literature on crisis management in the hospitality industry has gone through significant developments in recent years. This was done due to the unfortunate circumstances in which many countries experienced different crisis situations (Marketa et al., 2019).

Only a small number of studies have focused on the hotel managers as a unit of analysis and investigated his day to day combat with crisis situations in his business. One of the studies that evaluated what managers do during or immediately after a triggered crisis was conducted by Israeli and Reichel, (2003). 
This research also marks one of the first attempts to research crisis management of hotel managers in Egypt. Travel and tourism is a high-growth industry, forecast to increase its total economic activity by $4 \%$ worldwide in real terms over the next 10 years (WTTC, 2018).

The crisis in the Egyptian hotels industry (2011-2018) and in the Egyptian economy as a whole originates primarily from the instability of the Egyptian revolution 2011 and its adherents, also the instability in most of other Arabic countries regarding their revolutions. The most apparent outcome of this crisis is a sharp decline in the number of tourists arriving in Egypt (Abd Elzaher, 2019). In order to cope with this decline, the local hotels industry increases its reliance on the domestic market by offering a variety of package deals (Gamal \& EL-Hussin, 2017).

Also, the hotel management used many practices to face this situation, the decrease in foreign visitors is compensated for by an increase in domestic tourism, resulting in a change of consumer proportions. As a result, while in 2010, number of arrivals was 14 million the number turned down in the next years to be the lowest in 2016 by 5.3 million arrivals, the same was in the Number of Hotels \& resorts, Number of Rooms, Number of Nights, Number of Employees, Total income, total of salaries and the Number of beds.

\section{Objectives of the research}

- To explore the main practices using incase of crises in $3 \& 4$-star hotels in great Cairo and Sharm El Sheikh.

- To identify the relationship between the head of department's awareness about (the concept and functions) and (the Effects and Benefits) of the crises management plan (CMP) and the main practices using incase of crises in 3 \& 4-star hotels in great Cairo and Sharm El Sheikh.

\section{Literature review}

Okumus and Karamustafa (2005) agreed with Israeli and Reichel (2003) to present the process of creating a consistent list of practices for evaluating crisis management. The list of practices comprises four themes: marketing, infrastructure (or hotel) maintenance, human resources and governmental assistance. In each of the themes, moreover, Eugenio \& Campos (2014) and Nikolaos (2018) added one theme which Information Technology. On other hand Candemir \& Zalluhoglu (2011) add more one theme which is Cooperative Initiatives, practices relevant to the crisis in the hospitality industry was listed.

Table 1: The main practices used in case of crises

\begin{tabular}{|c|c|c|}
\hline Category & Practices & Author \\
\hline $\begin{array}{l}\text { Human } \\
\text { resources }\end{array}$ & $\begin{array}{l}\text { Firing employees to reduce labor force. } \\
\text { Using unpaid vacation to reduce labor force. } \\
\text { Decreasing number of working days per week. } \\
\text { Freezing pay rates. } \\
\text { Replacing high-tenure employees with line } \\
\text { employees. } \\
\text { Increased reliance on outsourcing. } \\
\text { Reduced our budget for training our employees. }\end{array}$ & $\begin{array}{l}\text { Mansfeld \& Pizam, } 2006 \\
\text { Nikolaos,2018 } \\
\text { Pearson et al., } 2007 \\
\text { Kouzmin, 2008 } \\
\text { Cretu \& Alvarez, } 2010 \\
\text { Candemir \& Zalluhoglu, } 2011 \\
\text { Okumus \& Karamustafa, } 2005\end{array}$ \\
\hline Marketing & $\begin{array}{l}\text { Marketing to domestic tourists and local merchants. } \\
\text { Marketing to domestic tourists with focus on specific } \\
\text { attributes of the location. } \\
\text { Price drop on special offers. } \\
\text { Reducing list price } \\
\text { Marketing to foreign tourists with specific focus on } \\
\text { the location's distinctive features and relative safety }\end{array}$ & $\begin{array}{l}\text { Naidoo, } 2010 \\
\text { Ukakturk, Bekmenzci, } \\
\text { Ukakturk, } 2011 \\
\text { Wang \& Ritchie, } 2012 \\
\text { Eugenio \& Campos, } 2014 \\
\text { Falk, } 2013\end{array}$ \\
\hline
\end{tabular}




\begin{tabular}{|c|c|c|}
\hline & $\begin{array}{l}\text { Marketing and promoting new products or services } \\
\text { (family events, catering) } \\
\text { Marketing to new segments. } \\
\text { Created awards from employee's ideas to reduce } \\
\text { costs and/or to increase sales. } \\
\text { Reduced the prices used to sell rooms }\end{array}$ & $\begin{array}{l}\text { Jia, Shi, Jia, \& Li, } 2012 . \\
\text { Seeger et al., } 2003 . \\
\text { Mitroff et al., } 2001 . \\
\text { Wang \& Ritchie, } 2012 .\end{array}$ \\
\hline \multirow{10}{*}{$\begin{array}{l}\text { Information } \\
\text { Technology }\end{array}$} & Use systematic links to further information & Nikolaos, 2018. \\
\hline & $\begin{array}{l}\text { Use multiple value-added features (key facts, maps, } \\
\text { itineraries, distances, news, photo gallery, GPS, etc) }\end{array}$ & Eugenio \& Campos, 2014. \\
\hline & Itineraries, distances, news, photo gallery, GPS. & Candemir \& Zalluhoglu, 2011. \\
\hline & $\begin{array}{l}\text { Increased the use of social media in our marketing } \\
\text { and promotion strategy. }\end{array}$ & Okumus \& Karamustafa, 2005 \\
\hline & $\begin{array}{l}\text { Increased the use of social media to better known } \\
\text { customers' needs and desires. }\end{array}$ & Nikolaos,2018 \\
\hline & $\begin{array}{l}\text { Make an effort to properly answering to positive and } \\
\text { negative comments uploaded online }\end{array}$ & Eugenio \& Campos, 2014 \\
\hline & $\begin{array}{l}\text { Entered into strategic partnership and alliances with } \\
\text { other companies to offer joint services }\end{array}$ & Eugenio \& Campos, 2014 \\
\hline & $\begin{array}{l}\text { Entered strategic partnership and alliances to make } \\
\text { co-marketing activities }\end{array}$ & Candemir \& Zalluhoglu, 2011 \\
\hline & $\begin{array}{l}\text { Entered strategic alliances with other companies to } \\
\text { jointly manage the buying process of product and } \\
\text { services (gasoil, official materials etc) with the aim } \\
\text { exploiting economies of scale }\end{array}$ & Nikolaos,2018 \\
\hline & Eentered into tourism consortia & Seeger et al., 2003 \\
\hline \multirow[t]{4}{*}{ Maintenance } & Cost cuts by limiting hotel services & Mansfeld \& Pizam, 2006 \\
\hline & Cost cuts by postponing maintenance of the building & $\begin{array}{l}\text { Ukakturk, Bekmenzci, \& Ukakturk, } \\
2011\end{array}$ \\
\hline & Cost cuts by changing suppliers & Wang \& Ritchie, 2012 \\
\hline & Extending credit or postponing scheduled payments & Eugenio \& Campos, 201 \\
\hline \multirow[t]{3}{*}{ Government } & $\begin{array}{l}\text { Organized protest against the lack of government } \\
\text { support. }\end{array}$ & Candemir \& Zalluhoglu, 2011 \\
\hline & $\begin{array}{l}\text { Industry-wide demand for governmental assistance } \\
\text { with current expenses }\end{array}$ & Mansfeld \& Pizam, 2006 \\
\hline & $\begin{array}{l}\text { Industry-wide demand for a grace period on tax } \\
\text { payments }\end{array}$ & Seeger et al., 2003 \\
\hline
\end{tabular}

\section{Research methods}

\section{Population and sample}

The current research is based on a quantitative-qualitative approach to achieve its aim. Data collection technique for the research will be a questionnaire to collect data from different head department managers at four \& three-star hotels in Cairo and Sharm El Sheikh which counted to 172 hotels Egyptian Hotel Guide (2019). Obtained data will be analyzed using SPSS version 22. The population of the research is the managers who counted (1548 nearly ) about 9 H.O.D`s in each hotel, The Central Agency for Public Mobilization and Statistics, (2019). So according to Khalifa and Ali (2017), the sample will be calculated according to the following formula:

$\mathrm{N}=$ Research Population $=1548$

$\mathrm{Z}=0.95=1.96$

$\mathrm{d}=0.05$

$$
n=\frac{N \times p(1-p)}{\left.\left[N-1 \times\left(d^{2} \div z^{2}\right)\right]+p(1-p)\right]^{\times N}}
$$


$\mathrm{p}=0.50$

$\mathrm{n}=387$

The total number of the questionnaire was 450 copies, distributed on four \& three-star hotels H.O.D. `s. or/and assistants as a random stratified sample, 400 were returned. The response rate reached $89 \%$.

\section{Sampling type}

According the Egyptian Hotel Guide (2019) there are 18 four-star hotels and 40 three-star hotels in great Cairo, on other hand there are 62 four-star hotels and 52 three-star hotels in Sharm ElSheikh.

In this study the researcher used a random stratified (staging) sample to collect data from the hotel department heads and Assistants in Cairo and Sharm El Sheikh. This staging sample includes four stages as follows:

1. Stage one: 42 questionnaires from 4-star hotels in Great Cairo

2. Stage two: 93 questionnaires from 3-star hotels in Great Cairo.

3. Stage three: 144 questionnaires from 4-star hotels in Sharm El Sheikh.

4. Stage four: 121 questionnaires from 3-star hotels in Sharm El Sheikh.

Table 2: sample stages

\begin{tabular}{|l|l|l|l|l|}
\hline \multirow{2}{*}{$\begin{array}{c}\text { Hotels } \\
\text { category }\end{array}$} & \multicolumn{2}{|c|}{ Cairo } & \multicolumn{2}{c|}{ Sharm El Sheikh } \\
\cline { 2 - 5 } & No. of Hotels & No. of questionnaires & No. of Hotels & No. of questionnaires \\
\hline $4^{*}$ & 18 & 42 & 62 & 144 \\
\hline
\end{tabular}

Great Cairo and Sharm El Sheikh City we have been chosen as the prime case research area because:

1. It is the most dominant social, political, economic, etc. center in Egypt.

2. According to the Chamber of Tourist Establishments (2019) and Egyptian Hotel Association (2019), Greater Cairo City and Sharm El Sheikh City include the biggest number of hotels in Egypt.

The researcher selected a sample of 400 four \& three-star hotels H.O.D.`s. and assistants for more validity. The research used a questionnaire for data collection. A modified questionnaire was designed to explore the levels of knowledge, attitudes, and practices among the head of departments and assistants that have a crisis effect on hotels' operation in Great Cairo and Sharm El sheikh. An investigation of developing H.O.D.'s and assistant's performance in case of crisis and catastrophes were carried out using multiple sources of data, including a questionnaire, observations of the business environment, and a review of documentation.

A questionnaire form was designed and distributed to the head of departments and assistances in the selected sample during the period between September 2019 - January 2020.

Testing Validity and Reliability For validity concerns, the survey was piloted on a sample of 30 hotels department heads and 3 academic professional's persons to check its face and content validity. The comments of questionnaire were considered in the final form, for reliability of constructs, Cronbach's Alpha Coefficient is used, which should have a value equal to or greater than (0.7).

Table 3: Reliability analysis for sub-domains

\begin{tabular}{|l|l|l|l|}
\hline Variable & No. items & Reliability & Validity \\
\hline CMP concept and Functions & 6 & 0.747 & 0.864 \\
\hline CMP Effects and Benefits & 15 & 0.895 & 0.946 \\
\hline Practices may use in case of crisis & 17 & 0.710 & 0.846 \\
\hline
\end{tabular}


The results show that the questions have a validity and reliability which exceeded (0.70) for all respondents.

\section{Questionnaire Design}

The practices were used to build a questionnaire that was made up of three parts. The first part collected demographic information from the respondents. The second part examined the awareness of booth of the head of department's awareness about (the concept and functions) and (the Effects and Benefits) of the crises management plan (CMP).

using a Likert scale of 1 -least important to 5-most important. The third part examined the level of importance managers assigned and the level of actual use for each of the 17 crisis management practices using the same Likert scale ranging from 1 - extensively used to 5rarely used.

The questionnaire was sent to 450 participants who included middle-level managers, department heads and other senior managers of different $3 \& 4$-star hotels in Cairo and Sharm El Sheikh. Responses were received from 400 participants (89\%). The sample group demographics are presented in Table 2. The majority were men. Ages ranged between 20 and 40 , and all of them held management positions.

The research has two main hypotheses for analyzing crisis management.

h1: There is a positive significant statistical relationship between the crisis management practices using incase of crises and the head of department's awareness about the concept and functions of crises management plan (CMP).

h2: There is a positive significant statistical relationship between the head of department's awareness about the CMP Effects and Benefits and the crisis management practices using incase of crises.

\section{Results}

Table 4: Descriptive Statistics of the Respondents

\begin{tabular}{|l|l|l|}
\hline Variable & Frequency No(n=450) & Percent \% \\
\hline Gender & & \\
\hline Male & 391 & 97.8 \\
\hline Female & 9 & 2.3 \\
\hline Age & & \\
\hline $20: 30$ & 45 & 11.3 \\
\hline $30: 40$ & 212 & 53.0 \\
\hline $40: 50$ & 108 & 27.0 \\
\hline $50: 60$ & 34 & 8.5 \\
\hline$>60$ & 1 & .3 \\
\hline Hotel Area & & \\
\hline Cairo & 139 & 34.8 \\
\hline Sharm & 261 & 65.3 \\
\hline category: & & \\
\hline 3 stars & 220 & 55.0 \\
\hline 4 Stars & 180 & 45.0 \\
\hline
\end{tabular}

According to table 4:

1- Most of respondents were males (97.8\%) and very few were females $(2.3 \%)$ which means that the hotels field not attracted for the female employees or there are not continued to be a manager.

2- Most of respondents ages between 30 to less than 50 years old 30:40 (53\%) followed by 40:50 $(27 \%)$ and very few over 50 years old $(8.8 \%)$ which means that the filed lost his 
experienced managers and also most of them changed their carrier before the fiftieth years' old

Table 5: Descriptive for the concept of crisis and crisis management plan

\begin{tabular}{|l|l|l|l|}
\hline The concept of crisis and crisis management plan & Range & Mean & Std. Deviation \\
\hline $\begin{array}{l}\text { A crisis is any situation that has the potential to affect long-term } \\
\text { confidence in an organization or a product, or which may interfere with } \\
\text { its ability to continue operating normally. }\end{array}$ & $2-5$ & 3.888 & 0.742 \\
\hline $\begin{array}{l}\text { CMP is a tool to consider every kind of possibility and give advice in } \\
\text { case a crisis happens. }\end{array}$ & $2-5$ & 3.898 & 0.830 \\
\hline CMP is a tool for the quick response to a possible threat & $2-5$ & 3.815 & 0.805 \\
\hline CMP is a tool to organize the performance in case a crisis happens. & $2-5$ & 3.963 & 0.638 \\
\hline CMP is a tool to minimize losses or damages. & $3-5$ & 4.075 & 0.762 \\
\hline $\begin{array}{l}\text { it is a written document outlining the official procedures applying in } \\
\text { case of crisis }\end{array}$ & $3-5$ & 4.418 & 0.574 \\
\hline
\end{tabular}

According to table 5, the concept (it is a written document outlining the official procedures applying in case of crisis) was highly respond, followed by the concept (CMP is a tool to minimize the losses or damages), which agreed with (Jie, 2018), (Wang \& Ritchie, 2012) and (Hartmann,2011)

table (6): - Descriptive for CMP Effects and Benefits

\begin{tabular}{|c|c|c|c|}
\hline CMP Effects and Benefits & Range & Mean & Std. Deviation \\
\hline 3/1- Minimize hotel loses & $2-5$ & 3.888 & 0.841 \\
\hline 3/2- Maximize hotel secure & $2-5$ & 3.988 & 0.941 \\
\hline 3/3- Minimize staff turn over & $1-5$ & 3.063 & 0.900 \\
\hline 3/4- Maximize staff loyalty & $2-5$ & 3.410 & 0.658 \\
\hline 3/5- Increase staff motivation & $2-5$ & 3.383 & 0.723 \\
\hline 3/6- Improving staff performance & $2-5$ & 3.610 & 0.836 \\
\hline 3/7- Team work building & $2-5$ & 3.730 & 0.737 \\
\hline 3/8-Maximize hotel profits & $2-5$ & 3.283 & 0.972 \\
\hline 3/9- Reorganize manning guide & $2-5$ & 3.605 & 0.745 \\
\hline 3/10- Hotel reputation improvement & $2-5$ & 3.518 & 0.994 \\
\hline 3/11- Increase hotel market share & $2-5$ & 3.828 & 0.710 \\
\hline 3/12- It is a competitive advantage for hotel & $2-5$ & 3.523 & 0.950 \\
\hline 3/13- Minimize of customers complaints & $2-5$ & 3.480 & 0.819 \\
\hline 3/14- Minimize of fines and compensations & $3-5$ & 3.835 & 0.692 \\
\hline 3/15- Not to withdraw licenses temporarily from the hotel & $3-5$ & 4.363 & 0.618 \\
\hline
\end{tabular}

According to Table 6, the most CMP Effects and Benefits is (Not to withdraw licenses temporarily from the hotel) with mean (4.363), followed by (Maximize hotel secure) with mean (3.988), followed by (Minimize hotel loses ) with mean (3.888), The Effect Or Benefit (Minimize staff turnover) seemed the least important factor with total mean (3.063).

Which agreed with (Chen, 2011), (Papatheodorou \& Arvanitis, 2014), Smeral, 2010), (Naidoo et. al., 2010) and (Marketa et. al., 2019).

Table 7: explained the ranking of The Practices may use in case of crisis from the higher to lowest with their means.

\begin{tabular}{|l|l|c|}
\hline The Practices may use in case of crisis & Mean & Std. Deviation \\
\hline 6/5- Replacing high-tenure employees with line employees & 4.64 & 0.597 \\
\hline 6/4-. Freezing pay rates & 4.503 & 0.553 \\
\hline $\begin{array}{l}\text { 6/12 Marketing and promoting new products or services (family } \\
\text { events, catering) }\end{array}$ & 4.355 & 0.711 \\
\hline
\end{tabular}




\begin{tabular}{|l|l|l|}
\hline The Practices may use in case of crisis & Mean & Std. Deviation \\
\hline 6/1- Firing employees to reduce labor force & 4.32 & 0.836 \\
\hline 6/3- Decreasing number of working days per week & 4.213 & 0.79 \\
\hline 6/9- Price drop on special offers & 4.19 & 0.895 \\
\hline 6/16 Cost cuts by changing suppliers & 4.145 & 0.656 \\
\hline 6/6- Increased reliance on outsourcing & 4.063 & 0.993 \\
\hline 6/13 Marketing to new segments & 4.023 & 0.713 \\
\hline $\begin{array}{l}\text { 6/10- use online customer service and support (FAQs, site map, site } \\
\text { search engine, chat, Skype, avatar, etc.) }\end{array}$ & 4.02 & 1.087 \\
\hline 6/2-. Using unpaid vacation to reduce labor force & 4.008 & 1.073 \\
\hline 6/15 Cost cuts by postponing maintenance of the building & 4.008 & 0.767 \\
\hline 6/17 Extending credit or postponing scheduled payments & 3.963 & 0.733 \\
\hline 6/14 Cost cuts by limiting hotel services & 3.948 & 0.694 \\
\hline $\begin{array}{l}\text { 6/8- increased the use of social media in our marketing and promotion } \\
\text { strategy and to better known customers' needs and desires. }\end{array}$ & 3.925 & 0.675 \\
\hline 6/7- Marketing to domestic tourists and local merchants & 3.57 & 1.176 \\
\hline $\begin{array}{l}\text { 6/11- Marketing to foreign tourists with specific focus on the location's } \\
\text { distinctive features and relative safety }\end{array}$ & 3.185 & 1.041 \\
\hline According to tabs 7, the most practices may use in case of crisis & \\
\hline
\end{tabular}

According to tables 7, the most practices may use in case of crisis is (replacing high-tenure employees with line employees ) with mean (4.64), followed by (freezing pay rates ) with mean (4.503), followed by (Marketing and promoting new products or services (family events, catering) ) with mean (4.355), followed by (firing employees to reduce labor force ) with mean (4.32), The Practices may use in case of crisis (Marketing to foreign tourists with specific focus on the location's distinctive features and relative safety) seemed the least important factor with total mean (3.185). Which agreed with (Pearson et al., 2007), (Kouzmin, 2008), (Cretu \& Alvarez, 2010), Nikolaos (2018) and (Mansfeld \& Pizam, 2006),

Table 8: Correlation co-efficient between methods which applied to develop the performance and scores of research sample $(n=400)$

\begin{tabular}{|l|l|l|}
\hline \multicolumn{2}{|c|}{ Correlations } & \multicolumn{1}{c|}{ Practices may use in case of crisis } \\
\hline \multirow{2}{*}{ CMP concept and Functions } & $\mathrm{r}$ & 0.683 \\
\cline { 2 - 3 } & $\mathrm{p}$ & $<0.001 * *$ \\
\hline \multirow{2}{*}{ CMP Effects and Benefits } & $\mathrm{r}$ & 0.739 \\
\cline { 2 - 3 } & $\mathrm{p}$ & $<0.001 * *$ \\
\hline
\end{tabular}

Statistically significant correlation at $\mathrm{P}$. value $<0.01$

According to the table 7:

H1: There is a positive significant statistical relationship between the crisis management practices using incase of crises and the head of department's awareness about the concept and functions of crises management plan (CMP) $(r=0.683)$ and $p$. value $<0.01$.

H2: There is a positive significant statistical relationship between the head of department's awareness about the CMP Effects and Benefits and the crisis management practices using incase of crises $(r=0.739)$ and $p$. value $<0.01$.

table (9): - Comparison between scores related to hotel area of research sample $(n=400)$

\begin{tabular}{|c|c|c|c|c|c|c|c|c|}
\hline \multirow{2}{*}{ Variable } & \multirow{2}{*}{$\begin{array}{l}\text { Max } \\
\text { Score }\end{array}$} & \multicolumn{2}{|l|}{ Cairo } & \multicolumn{2}{|l|}{ Sharm } & \multicolumn{2}{|l|}{ Total } & \multirow{2}{*}{ P. value } \\
\hline & & Mean & SD & Mean & SD & Mean & SD & \\
\hline $\begin{array}{l}\text { CMP concept and } \\
\text { Functions }\end{array}$ & 30 & 23.32 & 2.53 & 24.45 & 2.74 & 24.06 & 2.72 & $<0.001 * *$ \\
\hline $\begin{array}{l}\text { CMP Effects and } \\
\text { Benefits }\end{array}$ & 75 & 52.86 & 7.41 & 55.38 & 7.83 & 54.5 & 7.77 & $0.002 * *$ \\
\hline
\end{tabular}




\begin{tabular}{|l|l|l|l|l|l|l|l|l|}
\hline \multirow{2}{*}{ Variable } & Max & \multicolumn{2}{|l|}{ Cairo } & \multicolumn{2}{l|}{ Sharm } & \multicolumn{2}{l|}{ Total } & \multirow{2}{*}{ P. value } \\
\cline { 3 - 10 } & Score & Mean & SD & Mean & SD & Mean & SD & \\
\hline $\begin{array}{l}\text { Practices may use in } \\
\text { case of crisis }\end{array}$ & 85 & 67.73 & 4.31 & 69.79 & 5.03 & 69.08 & 4.89 & $<0.001^{* *}$ \\
\hline
\end{tabular}

- independent t-test* Significant difference at p. value $<0.05$, ** Significant difference at $\mathrm{p}$. value $<0.01$

- The respondents from SSH Hotels have more awareness about the CMP concept and Functions with mean of (24.45) while the respondents from Cairo hotel have less awareness with mean (23.32) with Significant difference at p. value $<0.01$.

- The respondents from SSH Hotels have more awareness about the CMP Effects and Benefits with mean of (55.38) while the respondents from Cairo hotel have less awareness with mean (52.86) with Significant difference at $\mathrm{p}$. value $<0.01$.

- The respondents from SSH Hotels more applied for the Practices may use in case of crisis with mean of (69.79) while the respondents from Cairo hotel less applied for the Practices may use in case of crisis with mean of (67.73) with Significant difference at p. value $<0.01$.

Table (10): - Comparison between scores related to category of research sample $(n=400)$

\begin{tabular}{|c|c|c|c|c|c|c|c|c|}
\hline \multirow{2}{*}{ Variable } & \multirow{2}{*}{$\begin{array}{l}\text { Max } \\
\text { Score }\end{array}$} & \multicolumn{2}{|l|}{3 stars } & \multicolumn{2}{|c|}{4 Stars } & \multicolumn{2}{|l|}{ Total } & \multirow{2}{*}{ P.value } \\
\hline & & Mean & SD & Mean & SD & Mean & SD & \\
\hline $\begin{array}{l}\text { CMP concept and } \\
\text { Functions }\end{array}$ & 30 & 22.04 & 1.59 & 26.52 & 1.49 & 24.06 & 2.72 & $<0.001 * *$ \\
\hline $\begin{array}{l}\text { CMP Effects and } \\
\text { Benefits }\end{array}$ & 75 & 48.25 & 4.34 & 62.14 & 2.25 & 54.5 & 7.77 & $<0.001 * *$ \\
\hline $\begin{array}{l}\text { Practices may use in } \\
\text { case of crisis }\end{array}$ & 85 & 65.97 & 3.73 & 72.87 & 3.15 & 69.08 & 4.89 & $<0.001 * *$ \\
\hline
\end{tabular}

- independent t-test $* *$ Significant difference at $\mathrm{p}$. value $<0.01$

- The respondents from four-star Hotels have more awareness about the CMP concept and Functions with mean of (26.52) while the respondents from three-star hotels have less awareness with mean (22.04) with Significant difference at p. value $<0.01$.

- The respondents from four-star Hotels have more awareness about the CMP Effects and Benefits with mean of (62.14) while the respondents from three-star hotels have less awareness with mean (48.25) with Significant difference at p. value $<0.01$.

- The respondents from four star Hotels more applied for the Practices may use in case of crisis with mean of (72.87) while the respondents from three star hotels less applied for the Practices may use in case of crisis with mean of (65.97). with Significant difference at p. value $<0.01$.

\section{Conclusion and limitations}

This research investigated the practices which used in the Egyptian hotels industry in case of crises. The research has tested one hypothesis of how these factors (CMP concept and functions awareness,) affecting the dependent variable (practices which used in case of crises). The research has used a questionnaire to collect data from 400 Managers to perceive their opinions on the factors affect Egyptian hotels. The research has revealed very useful results in the way it evaluated the perceptions of managers on the hotels and described the factors that hotels have succeeded to offer in their CMP. Meanwhile, the research has provided hotels managers with some feedback on the overall perception of their CMP and the practices better to use in case of crises. The research has indicated that Most of respondents in booth Cairo and SSh indicated that 
the most Practices may use in case of crisis is (Replacing high-tenure employees with line employees), followed by (Freezing pay rates), followed by (Firing employees to reduce labor force), which means that in case of any crisis the hotels industry lost a lot of experienced employees which very dangerous for the industry in case the crisis take a long term. And also The results from the research indicated that an overall average of the Practices may use in case of crisis in Sharm hotels more than in Cairo hotels.

\section{Limitations and future research}

According the research results the authors recommend the following:

1. The need to Issue a role to hire managerial levels employees to be have a minimum of qualifications and experiences required

2. The need to prepare a training courses for the hotels manager to train them how to manage the crises

3. The need to take an action against any unreason firing for employees.

4. The need to take an action against any stopping of salaries increase.

5. The need to prepare a role to organize the minimum experienced managers in each hotel

6. We need more research about the Egyptian hotels salary scales compared with other careers and countries.

\section{References}

Abd El- Zaher, Samar Nabil Khalaf, (2019). Crisis Management of Food Rumors and Its Impact on The Purchasing Decision of the Local Restaurant Customers in Fayoum City, PhD thesis, Faculty of Tourism and Hotels Department of Hotel Studies, Fayoum University.

Alas, R., Gao, J., \& Vanhala, S. (2010). The crisis management in Chinese and Estonian organizations. Chinese Management Studies, 4(1), 18-36.

Alonso-Almeida, M. D. M., Bremser, K., \& Llaeh, J. (2015). Proactive and reactive strategies deployed by restaurants in times of crisis: Effects on capabilities, organization and competitive advantage. International Journal of Contemporary Hospitality Management, 27(7), 1641-1661

Candemir, A., \& Zalluhoglu, A. (2011). The effect of marketing expenditures during financial crisis: The case of Turkey. Procedia Social and Behavioral Studies, 24, 291-299.

Center, A. H., Jackson, P., Smith, S., \& Stansberry, F. R (2008). Public relations practices: Managerial case studies and problems. Pearson Prentice Hall

Chen, M.-H. (2011). The response of hotel performance to international tourism development and crisis events. International Journal of Hospitality Management, 30(1), 200-2012.

Chong, I. K. (2004). Six steps to better crisis management. Journal of Business Strategy, 25(2), 43-46.

Coombs, W. T., \& Holladay, S. J. (2002). Helping crisis managers protect reputational assets: Initial tests of the situational crisis communication theory. Management Communication Quarterly, 16(2), 165-186.

Crandall, W. R., Parnell, T. A., \& Spillan, J. E. (2013) Crisis management: Leading in the new strategy landscape. Sage Publications.

Dirk Glaesser, (2006) Crisis Management in the Tourism Industry, Elsevier, Great Britain.

Eugenio-Martin, J. L., \& Campos-Soria, J. A. (2014). Economic crisis and tourism expenditure cutback decision. Annals of Tourism Research, 44, 53-73.

Falk, M. (2013) A survival analysis of ski lift companies. Tourism Management, 36, 377-390. 
Gamal S. A. Khalifa and EL-Hussin M.S. Ali (2017) Managing drivers and boundaries of information technology risk management (ITRM) to increase Egyptian hotels market share International Journal on Recent Trends in Business and Tourism, 1(1).

Hart, P., Heyse, L., \& Boin, A. (2001) New trends in crisis management practice and crisis management research: Setting the agenda. Journal of Contingencies and Crisis Management, 9(4),181-188.

Hartmann, Jana. (2011) Crisis Management of the Hotel Industry in Finland, Bachelor Thesis, HAAGA-HeLIA University of Applied Sciences.

Israeli, A.A. \& Reichel, A. (2003) Hospitality crisis management practices: The Israeli case. Int. J. Hospitality Management, 22(4), 353-372.

Jia, Z., Shi, Y., Jia, Y., \& Li, D. (2012). A framework of knowledge management systems for tourism crisis management. Procedia Engineering, 29, 138-143.

Jie Wanga, Xiaoyi Wu. (2018). Top-down or outside-in? Culturally diverse approaches to hotel crisis planning. Journal of Hospitality and Tourism Management 36, 76-84

Kovoor-Misra, S., Clair, J., Bettenhausen, K., (2001). Clarifying the attributes of organizational crises. Technological Forecasting and Social Change 67, 77-91.

Marketa Kubickovaa \& Destan Kirimhanb, Hengyun Lic. (2019). The impact of crises on hotel rooms' demand in developing economies: The case of terrorist attacks of 9/11 and the global financial crisis of 2008. Journal of Hospitality and Tourism Management, 38, 27-38

Mitroff, 1. 1. (2005) Why some companies emerge stronger and better from a crisis: 7 essential lessons for surviving disaster. AMACOM/American Management Association.

Mitroff, I. I., C. M. Pearson, and L. K. Harrigan. (2001) The essential guide to managing corporate crises: A step-by-step handbook for surviving major catastrophes. New York: Oxford University Press.

Mitroff, II, \&Anagnos, G (2001). Managing Crises Before They Happen: What Every Executive and Manager Needs to Know About Crisis Management. American Management Association.

Naidoo, P., Ramseook-Manhurun, P., \& Seetaram, A. K. (2010). Marketing the hotel sector in economic crisis: Evidence from Mauritius. Global Journal of Business Research, 5(2), 1-12.

Naidoo, V. (2010). Firm survival through a crisis: The influence of market orientation, marketing innovation and business strategy. Industrial Marketing Management, 39(8), 1311-1320.

Nikolaos Pappas. (2018) Hotel decision-making during multiple crises: A chaordic perspective. Journal of Tourism Management 68, 450-464

Okumus, F., \& Karamustafa, K. (2005). Impact of an economic crisis: Evidence from Turkey. Annals of Tourism Research, 32(4), 942-961.

Ozdemir, L. (2016). The Positive and Negative Effects of Crisis on Organizations: An Application, 4(1).

Paula MadalinaCretu\& Jonathan Puentes, (2010). Managing Organizational Crises in the Light of Political Unrest, The "Gulf Agency Company" Egypt Case, Master of Science in Business Administration Strategy and Management in International Organizations, Linköping, Sweden. 
Pearson R.G., Raxworthy C.J., Nakamura M., Peterson A. Townsend. (2007). Predicting species distributions from small numbers of occurrence records: a test case using cryptic geckos in Madagascar J. Biogeogr., 34, 102-117.

Qoura, O. E., \& Ali, E. (2015). Energy Saving and Green Practices in the Cairo Five-Star Hotels: An Exploratory Study. International Journal of Heritage, Tourism, and Hospitality, 9 (1).

Ritchie, B. (2008). Tourism disaster planning and Management: From response and recovery to reduction and readiness. Current Issues in Tourism, 11(4), 315-348.

Seeger, M. W., Ulmer, R. R., Novak, J. M., \& Sellnow, T. (2005). Post-crisis discourse and organizational change, failure and renewal. Journal of Organizational Change Management, 18(1), 78-95.

Seeger, MW, Sellnow, TL, \& Ulmer, RR (2003). Communication and Organizational Crisis, Preager Publishers.

Smith, D, \& Elliot, D (2006). Key Readings in Crisis Management: Systems and Structures for Prevention and Recovery, Routledge Publishers.

Song, H., Lin, S., Witt, S. F., \& Zhang, X. (2011). Impact of financial/economic crisis on demand for hotel rooms in Hong Kong. Tourism Management, 32(1), 172-186.

Susana Cro, Antonio Miguel Martins. (2017). Structural breaks in international tourism demand: Are they caused by crises or disasters? Journal of Tourism Management, 63, 3-9.

Tsaur, S.H., Lin, Y.C. (2004). Promoting service quality in tourist hotels: the role of HRM practices and service behavior, Tourism Management, 25(4), 471-481.

Ukakturk, A., Bekmenzci, M., \& Ukakturk, T. (2011) Prevailing during periods of economic crisis and recession through business model innovation. Procedia: Social and Behavioral Studies, 24, 89-100.

Wang, J., \& Ritchie, B. W. (2012) Understanding accommodation managers' crisis planning intention. An application of the theory of planned behavior. Tourism Management, 33(5), $1057-1067$.

WTTC, (2018). World Travel \& Tourism Council, Economic Impact Reports. 